\title{
Analysis and Simulation of Proportional Derivative and Proportional Integral Derivative Control Systems Using Xcos Scilab
}

\author{
Edi Kurniawan $^{1^{*}}$, Kerista Sebayang ${ }^{2}$, and Fani Sasmita Simbolon ${ }^{3}$ \\ ${ }^{1}$ Physics Research Centre LIPI, Kawasan Puspiptek, Serpong, Tangerang Selatan, Banten 15314, \\ Indonesia \\ ${ }^{2.3}$ Department of Physics, Faculty of Mathematics and Natural Science, Universitas Sumatera Utara, \\ Medan 20155, Indonesia
}

\begin{abstract}
PID (Proportional Integral Derivative) control is a popular control in the industry and aims to improve the performance of a system. This control has controlling parameters, namely $\mathrm{K}_{\mathrm{p}}, \mathrm{K}_{\mathrm{i}}$, and $\mathrm{K}_{\mathrm{d}}$ which will have a control effect on the overall system response. In this research, P, PD, and PID control simulations with the transfer function of the massdamper spring as a plant using Xcos Scilab. The method used is the trial and error method by setting and varying the values of the control constants $\mathrm{K}_{\mathrm{p}}, \mathrm{K}_{\mathrm{i}}$, and $\mathrm{K}_{\mathrm{d}}$ to produce the desired system response. The value adjustment of system control parameters is carried out with several variations, namely $K_{p}$ control variation, $K_{p}$ variation to constant $K_{d}, K_{d}$ variation to constant $\mathrm{K}_{\mathrm{p}}, \mathrm{K}_{\mathrm{p}}$ variation to $\mathrm{K}_{\mathrm{i}}$, constant $\mathrm{K}_{\mathrm{d}}$, variation of $\mathrm{K}_{\mathrm{i}}$ to $\mathrm{K}_{\mathrm{p}}$, constant $\mathrm{K}_{\mathrm{d}}$ and variation of $\mathrm{K}_{\mathrm{d}}$ to $\mathrm{K}_{\mathrm{p}}$, $\mathrm{K}_{\mathrm{i}}$ constant. The second method is automatic tuning which is done through mathematical calculations to obtain PID control constants, namely Zieglar Nichols PID tuning with the oscillation method. From the system simulation results, the best parameter is obtained through the Zieglar Nichols PID tuning process based on the results of the transient response analysis, namely when the proportional gain value $\left(\mathrm{K}_{\mathrm{p}}\right)$ is 50. The system performance characteristics produced in the tuning process are 3.994 seconds of settling time at 2.36 seconds research time. resulting in a maximum overshoot value of $3.6 \%$ and a peaktime value of 3.994 seconds.
\end{abstract}

Keyword: P control, PD, PID, PID tuning, Xcos Scilab, Zieglar-Nichols

Received 5 February 2021 | Revised [19 February 2021] | Accepted [25 February 2021]

\section{Introduction}

PID (Proportional Integral Derivative) control is a development of conventional control which aims to provide the best control effect on a control system [1]. PID control is structurally simple and can be applied in general to a structure that is simple and easy to understand [2]. PID control is a basic control structure that has been used successfully in many industrial applications [3]. The PID control system is a controller to determine the precision of an instrumentation system with the characteristics of feedback on the system [4]. The purpose of

*Corresponding author at: Physics Research Centre LIPI, Kawasan Puspiptek, Serpong, Tangerang Selatan,

Banten 15314, Indonesia.

E-mail address: edi.kurniawan@lipi.go.id 
the PID control system is to improve the performance of a system. PID is defined through three control parameters, namely Proportional $\left(\mathrm{K}_{\mathrm{p}}\right)$, Integral $\left(\mathrm{K}_{\mathrm{i}}\right)$ and Derivative $\left(\mathrm{K}_{\mathrm{d}}\right)$. It has been found empirically that PID controllers are able to solve various control problems. There are more complex controllers that differ from PID controllers by using more sophisticated methods [5].

PID can be a component of process control due to its effectiveness, simplicity of implementation structure and ease of tuning its control parameters [6]. In a control system we know there are several kinds of control actions where each of these control actions has certain advantages. These parameters have a different influence on the achievement of the specified system performance so that it needs to be combined to complete the shortcomings of each parameter [7]. A proportional controller is a controller that produces an output whose value is directly proportional to the error value. An integral controller is the sum of errors at any time and accumulating offsets that have previously been corrected. Derivative controllers predict sise behavior and then improve system time and stability [8]. Proportional Integral Derivative (PID) controller parameters are always based on a review of plant characteristics. Thus, however complicated a plant is, the behavior of the plant must be known first before the search for PID parameters is carried out [9].

This research uses mass-damper spring system model as plant. Modeling a plant is not difficult to do as long as the plant is low-level. Difficulties will arise when the plant modeled high-level [10]. System modeling is represented by the mathematical equation of the transfer function. The system is based on closed lup control using measurement of output signal and reverse signal to be compensated/compared to desired input/reference input/command input [11]. This research was conducted by simulating the control system by determining the price of different proportional, integral and derivative controller constants that will optimize system performance. The constant adjustment of $\mathrm{K}_{\mathrm{p}}, \mathrm{K}_{\mathrm{i}}$ and $\mathrm{K}_{\mathrm{d}}$ is done by trial and error method and will result in the highlighting of the properties of each element. One of the three constants will vary to a constant and can be adjusted more prominently than the other. Variable constants will contribute to the influence of the overall system response.

The result of system performance specification provides information about transient response to time domain. Transient response can be determined from the measurement of frequency response to plants and actuators and the response of open loop frequencies to closed loops [12]. The system performance seen is rise-time, overshoot, peak time and settling-time against the input given. Another method used is by automatically PID tuning method Zieglar Nichols (Z$\mathrm{N})$. The Ziegler-Nichols (Z-N) design is the most popular heuristic method used in process control to determine controller PID parameters [13]. This method has two ways, namely the oscillation method and the reaction curve. The Ziegler-Nichols method used is the oscillation method. The oscillation method is a method of reasoning based on the reaction of the closed 
loop system [14]. Mathematical calculation of the system is based on Root-Hurwitz criteria for gain value and critical period to be used in Zieglar-Nichols PI and PID tuning process.

The control system methods used are simulated using several supporting software. One of the software that can be used for PID simulation is Scilab with a special toolbox for simulation named Xcos. Xcos is a diagram block editor for modeling and simulation of mixed dynamic systems including continuous and discrete models. Xcos consists of three elements: Editor, Pallete browser, and Simulator. The editor is the place to design the system to be built. This design is in the form of flow chart, starting from system input, process and system output Part two is a browser palette containing blocks that have been grouped by categories, such as continuous systems, discrete systems, mathematical operations, matrices, electrical and others. The last part is the simulator. Dynamic systems that have been designed then simulated, in the form of graphics for example, using the simulator Xcos [15].

\section{Methods}

This research was conducted at the Control System Laboratory of the LIPI Physics Research Center Gd. 442 Serpong PUSPITEK area, Setu Village, South Tangerang City, Postal Code 15310, Banten Province, starting from 03 February 2020 to 31 May 2020. The research flowchart is given in Figure 1; the base system remains a mass-damper spring is depicted in Figure 2 .

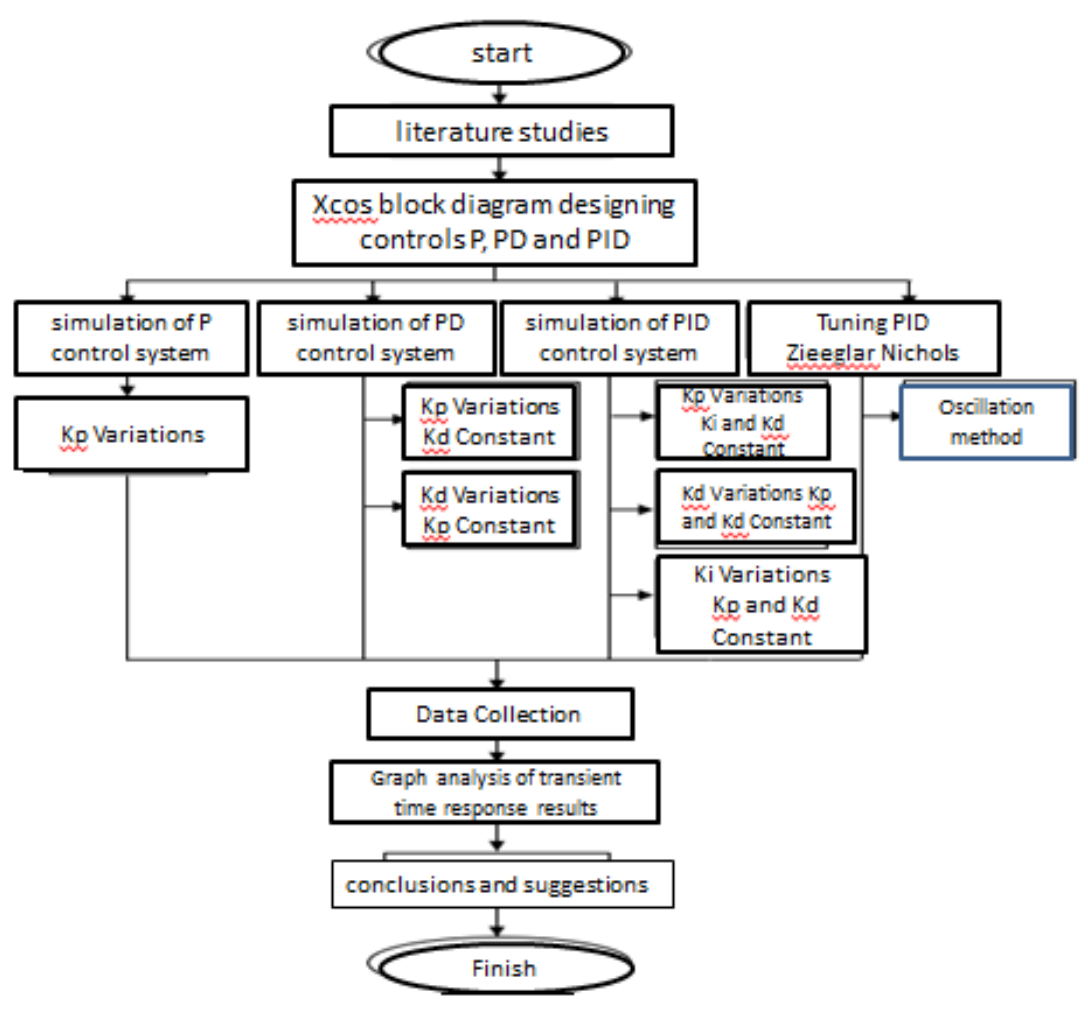

Figure 1. Research flowchart 


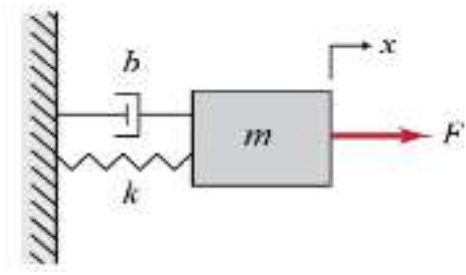

Figure 2. The base system remains a mass-damper spring [16].

Plant is a set of equipment consisting of several machine parts that function together to carry out a certain operation [17].

The transfer function between the force input $\mathrm{F}(\mathrm{s})$ and the displacement output $\mathrm{X}(\mathrm{s})$ becomes:

$\frac{X(s)}{F(s)}=\frac{1}{m s^{2}+b s+k}$

For known:

$m=1 \mathrm{~kg}$

$b=10 \mathrm{Ns} / \mathrm{m}$

$k=20 \mathrm{~N} / \mathrm{m}$

$F=1 N$

Substitute the known values into the transfer function above

$\frac{X(s)}{F(s)}=\frac{1}{s^{2}+10 s+20}$

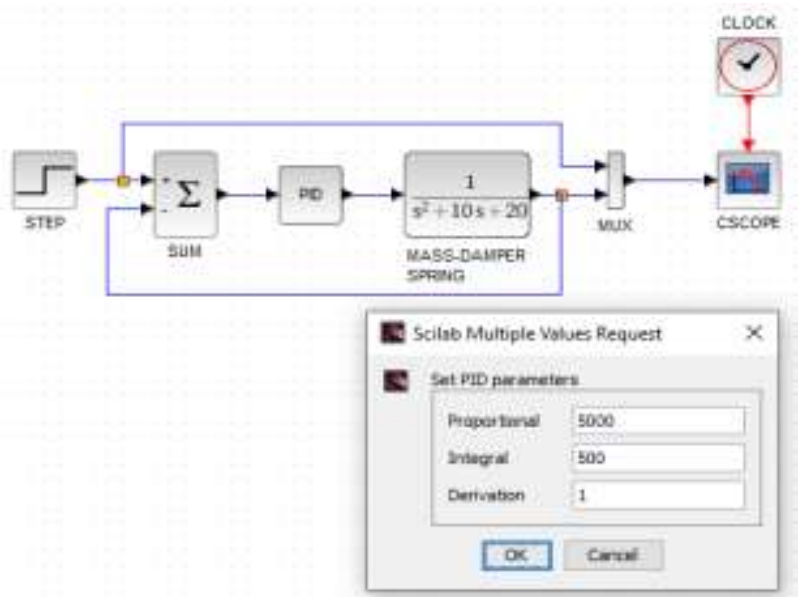

Figure 3. PID control system block diagram with constant $\mathrm{Kp}$ and $\mathrm{Ki}$ and $\mathrm{Kd}$ variation

Table 1 gives Zieglar-Nichols Tuning Rules based on Gain and Critical Period with the oscillation method, and Figure 4 gives Zieglar-Nichols PID Tuning Simulation.

Table 1. Zieglar-Nichols Tuning Rules based on Gain and Critical Period with the oscillation method [18]

\begin{tabular}{cccc}
\hline Control Type & $\boldsymbol{K}_{\boldsymbol{p}}$ & $\boldsymbol{T}_{\boldsymbol{i}}$ & $\boldsymbol{T}_{\boldsymbol{d}}$ \\
\hline $\mathbf{P}$ & $0.50 K_{c r}$ & $\infty$ & 0 \\
PI & $0.45 K_{c r}$ & $\frac{1}{12} P_{c r}$ & 0 \\
& & $0.5 P_{c r}$ & $0.125 P_{c r}$ \\
\hline
\end{tabular}




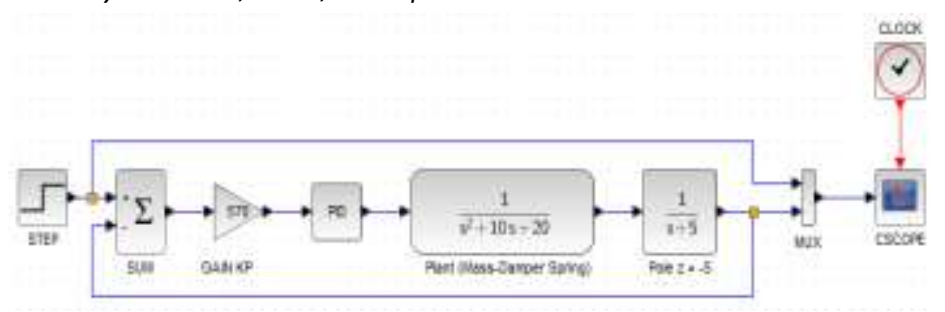

Figure 4. Zieglar-Nichols PID Tuning Simulation

Time response characteristics are response characteristics where the performance specifications are based on observing the form of system output response to time changes. The parameters used to measure the quality of transient responses in second-order systems include [19].

1. Rise time $\left(\mathrm{t}_{\mathrm{r}}\right)$, the time it takes for the response to increase from $10 \%$ to $90 \%, 5 \%$ to $95 \%$, or $0 \%$ to $100 \%$ of the final value. For second-order underdamped systems, the usual time is $0 \%$ to $100 \%$ and for overdamped systems the time goes up by $10 \%-90 \%$

2. Peak time $\left(\mathrm{t}_{\mathrm{p}}\right)$, peak time is the time required for the response to reach the first peak of the overshoot.

3. Maximum (percent) overshoot $\left(\mathrm{M}_{\mathrm{p}}\right)$, is the maximum peak value of the response curve. Maximum percent overshoot $=\frac{C\left(t_{p}\right)}{C(\infty)} \times 100 \%$. The maximum amount of overshoot (percent) directly indicates the relative stability of the system.

4. Settling time $\left(t_{s}\right)$, is the time it takes for the response curve to reach and stay there within the range of the final grade determined by the percentage of the final grade (usually $2 \%$ or $5 \%$ ) [20].

\section{Result and Discussion}

The control system is simulated by varying the value of one constant against another constant. Several variations of the values have the best and worst responses seen from the results of the graph of the output signal to the step signal input whose performance specifications provide information about the transient response in the time domain.

\subsection{Trial and error method}

The simulation of the PID control system is carried out by varying the different constants in the Kd parameters against the constant $\mathrm{K}_{\mathrm{p}}$ and $\mathrm{K}_{\mathrm{i}}$. The system response can be seen from the results of the output signal graph to the step signal input whose performance specifications are shown in Table 2 which provides information about the transient response in the time domain. 
Table 2. The results of the transient response of the PID control system with a constant variation of $\mathrm{Kp}$ to $\mathrm{Ki}$ and $\mathrm{Kd}$

\begin{tabular}{ccccccc}
\hline $\mathbf{K}_{\mathbf{p}}$ & $\mathbf{K}_{\mathbf{i}}$ & $\mathbf{K}_{\mathbf{d}}$ & $\begin{array}{c}\text { Rise } \\
\text { time }(\boldsymbol{s})\end{array}$ & $\begin{array}{c}\text { Max. } \\
\text { overshoot } \\
(\%)\end{array}$ & $\begin{array}{c}\text { Peak } \\
\text { time }(\boldsymbol{s})\end{array}$ & $\begin{array}{c}\text { Settling } \\
\text { time }(\boldsymbol{s})\end{array}$ \\
\hline $\mathbf{5 0 0 0}$ & 500 & 1 & 1.183 & 12.1 & 1.3 & 1.556 \\
$\mathbf{5 0 0 0}$ & 500 & 25 & 1.147 & 0 & 0 & 1.208 \\
$\mathbf{5 0 0 0}$ & 500 & 50 & 1.095 & 0 & 0 & 1.170 \\
$\mathbf{5 0 0 0}$ & 500 & 75 & 1.091 & 0 & 0 & 1.099 \\
$\mathbf{5 0 0 0}$ & 500 & 100 & 1.090 & 0.4 & 0 & 1.098 \\
$\mathbf{5 0 0 0}$ & 500 & 125 & 1.090 & 0 & 0 & 1.098 \\
$\mathbf{5 0 0 0}$ & 500 & 150 & 1.092 & 0 & 0 & 1.113 \\
$\mathbf{5 0 0 0}$ & 500 & 175 & 1.094 & 0 & 0 & 1.160 \\
$\mathbf{5 0 0 0}$ & 500 & 200 & 1.097 & 0 & 0 & 1.178 \\
$\mathbf{5 0 0 0}$ & 500 & 225 & 1.105 & 0 & 0 & 1.189 \\
\hline
\end{tabular}

\subsection{PID tuning parameters using the Zieglar-Nichols method}

In the PI and PID tuning process, the plants used are slightly different with the addition of a pole $(\mathrm{s}+5)$. This tuning rule uses the Z-N method with the oscillation method and the first step is to find the $\mathrm{K}_{\mathrm{cr}}$ and $\mathrm{P}_{\mathrm{cr}}$ values. The Kcr value is used from the Routh Hurwitz stability method.

Routh-Hurwitz stability criteria

Model G (s) when adding pole $\mathrm{z}=-5$

$G(s)=\frac{1}{\left(s^{2}+10 s+20\right)(s+5)}=\frac{K_{c r}}{s^{3}+15 s^{2}+70 s+100+K_{c r}}$

The characteristic equation obtained is based on the denominator coefficient (denumerator) of the system transfer function, namely:

$s^{3}+15 s^{2}+70 s+100+K_{c r}=0$

Table 3. The Routh Hurwitz criteria for calculating the Routh Hurwitz method will obtain a $\mathrm{K}_{\mathrm{cr}}$ value, as follows:

\begin{tabular}{|c|c|c|}
\hline$s^{3}$ & 1 & 70 \\
\hline$s^{2}$ & 15 & $\begin{array}{l}100 \\
+K\end{array}$ \\
\hline$s^{1}$ & $(15 \times 70)-\left(100+K_{c r}\right)$ & \\
\hline$s^{0}$ & $\begin{array}{c}15 \\
100+K_{c r}\end{array}$ & \\
\hline
\end{tabular}

$$
\begin{aligned}
\frac{1050-\left(100+K_{c r}\right)}{15}>0 & \\
-\left(100+K_{c r}\right) & >-1050 \\
K_{c r} & =950
\end{aligned}
$$

To determine the values of $T_{i}$ and $T_{d}$ by performing calculations looking for the value of continuous oscillation frequency $\left(P_{\mathrm{cr}}\right)$ by substituting $s=j \omega$ into the characteristic equation $\left(s^{3}+15 s^{2}+70 s+1050=0\right)$, to be 
$-j \omega^{3}-15 j \omega^{2}+70 j \omega+1050=0$

$\omega=\sqrt{70}=8.637$

Therefore, the continuous oscillation period obtained is:

$P_{c r}=\frac{2 \pi}{\omega}=\frac{6.28}{8.367}=0.75$

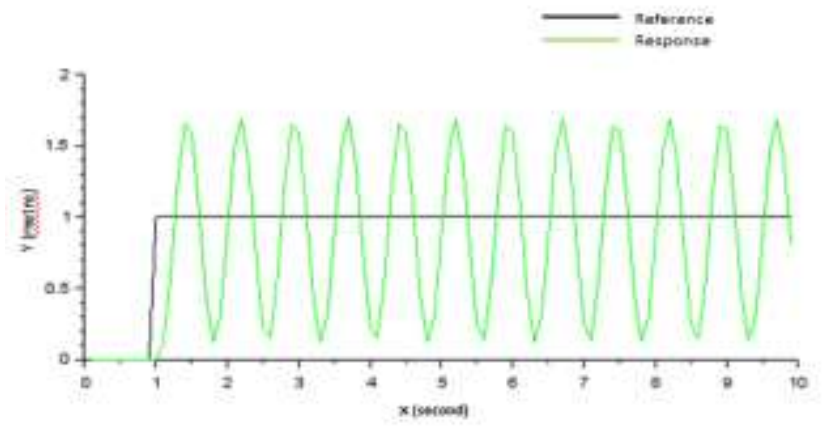

Figure 5. Graph of control system response results with $\mathrm{Kcr}=950$

Figure 5 shows that when $K_{\mathrm{cr}}=950$ can produce sinusoidal output. After obtaining a synergistic output, the PI and PID tuning process is carried out by entering the values that have been obtained.

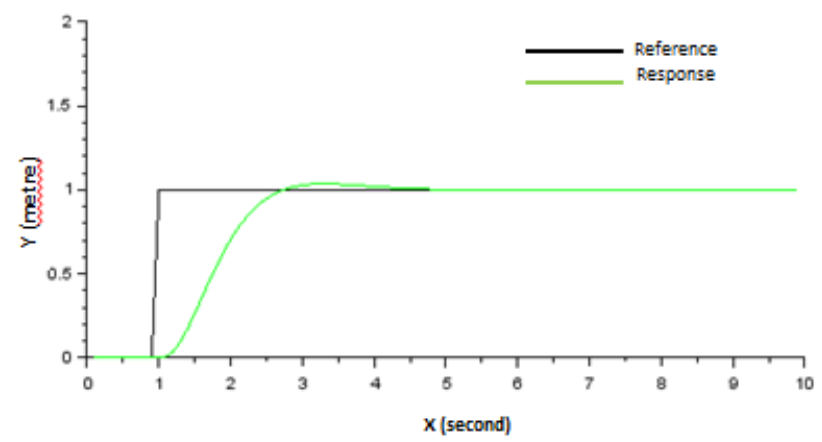

Figure 6. Graph of the response results for Zieglar-Nichols PID tuning with $\mathrm{Kp}=50$

Table 4 is the table of Zieglar Nichols PI and PID tuning results.

Table 4. Zieglar-Nichols PI and PID Tuning Results

\begin{tabular}{c|ccccc}
\hline $\begin{array}{c}\text { Control } \\
\text { Type }\end{array}$ & $K_{p}$ & Risetime (s) & $\begin{array}{c}\text { Max. } \\
\text { Overhoot } \\
(\%)\end{array}$ & Peaktime (s) & $\begin{array}{c}\text { Settling time } \\
(\mathrm{s})\end{array}$ \\
\hline PI & 427.5 & \multicolumn{4}{c}{ Continuous oscillation } \\
& 4.5 & 3.411 & 3 & 4.9 & 5.77 \\
& 570 & 1.31 & 52.9 & 1.55 & 3.079 \\
& 310 & 1.409 & 45.2 & 1.70 & 3.289 \\
& 50 & 2.36 & 3.6 & 3.30 & 3.994 \\
\hline
\end{tabular}

The results of the transient response of Zieglar Nichols tuning PI and PID in Table 4 show that the system performance specifications in the Zieglar Nichols PID tuning process produce transient response values to the time domain. This result is better than Zieglar Nichols' PI tuning. This is because in PI tuning there is no controller action that can produce output to correct the error value or there is no action that can 
anticipate the error generator so that the response generated when the gain is 427.5 continuous oscillations.

\section{Conclusion}

The best parameter of the PID control system using the trial and error method occurs when a constant variation of $K_{d}$ against $K_{p}$ and $K_{i}$ is carried out, namely when $K_{p}=5,000, K_{i}=500$, and $\mathrm{K}_{\mathrm{d}}=125$ produce a transient response to research time and settling time of 1.090 seconds and 1.098 seconds and the error value (overshoot) is zero. The best parameters generated when using the Zieglar-Nichols PID tuning method when the value of $\mathrm{K}_{\mathrm{p}}=50$ resulted in a response to research time, settling time, and overshoot of 2.36 seconds, 3.994 seconds and 3.6\%. Scilab is an open source high-level programming language available under a free license. Ease of use Scilab Tools can model and simulate dynamic systems. Modeling uses graphics where Xcos consists of diagram blocks with specific functions.

\section{REFERENCES}

[1] P.A. Priyono, "Pengembangan Media Pembelajaran Kontrol Pid Menggunakan Line Follower Robot Pada Mata Kuliah Sistem Kendali", Doctoral dissertation, Universitas Pendidikan Indonesia, 2016.

[2] K. H. Ang, G. Chong, and Y. Li, "PID control system analysis, design, and technology" IEEE transactions on control systems technology, vol. 13, no. 4, pp.559-576, 2005.

[3] S. L. Campbell, J. P. Chancelier, and R. Nikoukhah, Modeling and Simulation in SCILAB. In Modeling and Simulation in Scilab/Scicos with ScicosLab 4.4, New York: Springer, pp. 73-106, 2010.

[4] M. Yusuf, I. Isnawaty, and R. Ramadhan, Implementasi Robot Line Follower Penyiram Tanaman Otomatis Menggunakan Metode Proportional-Integral-Derivative Controller (PID)", semanTIK, vol. 2, no. 1, 2016.

[5] K. J. Åström, T. Hägglund, and K. J. Astrom, Advanced PID control (Vol. 461). Research Triangle Park: ISA-The Instrumentation, Systems, and Automation Society, 2006.

[6] I. Setiawan, Kontrol PID untuk proses industri. Jakarta: Elex Media Komputindo, 2013.

[7] P. Jati, S. Sunarno, and S. Sujarwata, "Simulasi kendali proportional integral derivative dan logika fuzzy pada sistem eksitasi automatic voltage regulator dengan simulink Matlab", Physics Communication, vol. 1, no.1, pp.93-98, 2017.

[8] K. Rosada, Sistem Kontrol Pompa Air Menggunakan Kontroler PID Berbasis Raspberry Pi, Doctoral dissertation, Institut Teknologi Sepuluh Nopember, 2017.

[9] A. Naufal, Analisa Simulasi Dan Penentuan Parameter Sistem Pengendali PID Pada Pelontar Peluru Plastik Dua Sumbu Putar, Doctoral dissertation, Institut Teknologi Sepuluh Nopember, 2016.

[10] F. Suryatini, and A. Firasanti, Kendali P, PI, Dan PID Analog Pada Pengaturan Kecepatan Motor DC Dengan Penalaan Ziegler-Nichols. JREC (Journal of Electrical and Electronics), vol. 6, no.1, pp.65-80, 2018.

[11] E. Yudaningtyas, Belajar Sistem Kontrol: Soal dan Pembahasan, Universitas Brawijaya Press, 2017.

[12] D. K. Anand, Introduction to control systems (Vol. 8), Elsevier, 2013.

[13] M. A. Unar, D. J. Murray-Smith, and S. A. Shah, Design and tuning of fixed structure PID controllers-a survey, Doctoral dissertation, University of Glasgow, Glasgow, 
Scotland, UK, 1995.

[14] M. B. Nugraha, and R. Sumiharto, "Penerapan Sistem Kendali PID pada Antena Pendeteksi Koordinat Posisi UAV”, IJEIS, vol. 5, no. 2, pp.187-198, 2015.

[15] N. Hadi, Analisis Repetitive Control untuk Rejection Multiple Periodical Disturbances dengan Menggunakan Scilab Xcos, Skripsi, Universias Islam Negeri Syarif Hidayatullah, (2018).

[16] Anonymous, Introduction: PID Controller Design. Available from http://ctms.engin.umich.edu/CTMS/index.php?example=Introduction\&section=ControlPI D. [ Accessed: March, 2020].

[17] G. C. Goodwin, S. F. Graebe, and M. E. Salgado, Control system design. Upper Saddle River, NJ: Prentice Hall, 2001.

[18] N. S. Nise, N. S. Control Systems Engineering Sixth Edition, California : John Wiley \& Sons, Inc, 2011.

[19] D. W. Wardhana, Perancangan sistem kontrol PID untuk pengendali sumbu azimuth turret pada turret-gun kaliber 20mm, Doctoral dissertation, Institut Teknologi Sepuluh Nopember, 2016.

[20] K. Ogata, Modern Control Engineering Fifth Edition, United States of America : Prentice Hall, 2010. 